\title{
Prospective Outcomes of Arthroscopic Versus Open Resection of Dorsal Wrist Ganglions
}

\author{
El Bileği Dorsal Ganglionlarının Artroskopik ve Açık Olarak Eksizyonlarının Sonuçları
}

\author{
(D) Tahsin Gürpınar, (D) Engin Çarkçı \\ University of Health Sciences Turkey, İstanbul Training and Research Hospital, Clinic of Orthopedics and Traumatology, İstanbul, Turkey
}

\begin{abstract}
Introduction: The aim of this prospective randomized study was to compare recurrence, pain and functional scores of the patients operated openly or arthroscopically due to dorsal wrist ganglion with a minimum of 18-month follow-up.

Methods: Twenty patients underwent arthroscopic and 20 patients underwent open excision after the failure of conservative treatment for a minimum period of six months. Patients' demographic characteristics, The Disabilities of the Arm, Shoulder and Hand score (QuickDASH), grip strength, Visual Analogue Pain scale (VAS), operation time, incision lengths, recurrence rates and treatment satisfaction rates were compared.
\end{abstract}

Results: In open and arthroscopy groups, age, gender, side distribution and dominant side distribution did not vary significantly $(p>0.05)$. Although the postoperative QuickDASH score and VAS decreased significantly in the open and arthroscopic groups, there was no significant difference between the groups. The duration of operation was significantly higher and the incision length was lower in the arthroscopy group than in the open excision group $(p<0.05)$. In the open and arthroscopic groups, time from diagnosis to surgery, grip strength, the rate of satisfaction with the treatment, and the recurrence rate were not significantly different $(p>0.05)$. Furthermore, we diagnosed scapholunate interosseous ligament tear in seven patients and grade 1 triangular fibrocartilage complex tear in one patient who underwent arthroscopic ganglion excision. In both of the groups, there were two recurrences during follow-ups (10\%), which were treated with open excision.

Conclusion: Arthroscopic ganglionectomy has the advantages of smaller incisions, diagnosing and intervention of other associated wrist pathologies. Disadvantages are steep learning curve and long operating time.

Keywords: Wrist arthroscopy, dorsal ganglion, arthroscopic ganglion excision

\section{öZ}

Amaç: Bu çalıșmanın amacı artroskopik veya açık yöntemlerle el bileği dorsal ganglion eksizyonu yapılan ve minimum 18 ay takip süresi olan hastaları fonksiyonel skor, rekürrens ve postoperatif ağrı açısından karşılaştırmaktır.

Yöntemler: Bu çalışmada el bileği dorsal ganglionu nedeniyle en az altı aylık konservatif tedaviye yanıt alınamamış 20 hasta artroskopik olarak ve 20 hasta açık cerrahi ile opere edilmiştir. Hastaların demografik özellikleri, Kol, Omuz ve El Sorunları Anketi (QuickDASH) skorları, kavrama gücü ve görsel ağrı skorları (VAS) kaydedildi. Her iki grup klinik sonuçlar, operasyon süresi, insizyon uzunluğu, rekürrens ve hasta memnuniyetleri açısından değerlendirildi.

Bulgular: Açık ve artroskopik gruplar arasında yaş, cinsiyet ve taraf açısından anlamlı bir fark saptanmadı ( $p>0,05)$. Her iki grupta da post-op dönemde QuickDASH skoru ve VAS anlamlı olarak düştü, ancak her iki grup arasında fark saptanmadı. Artroskopik grupta operasyon süresi anlamlı olarak uzun ve insizyon uzunluğu anlamlı olarak kısa bulundu $(p<0,05)$. Her iki grupta operasyona kadar geçen süre, kavrama gücü, hasta memnuniyeti ve rekürrens arasında anlamlı fark saptanmadı $(p>0,05)$. Yedi hastada skafolunat ligament yırtığı ve bir hastada Triangular fibrokartilaj kompleks yırtığı saptandı. Her iki hasta grubunda da iki rekürrens saptandı (\%10) ve açık olarak tedavi edildi.

Sonuç: Artroskopik ganglionektomi açık cerrahi ile karșılaştırıldığında daha az skar uzunluğu ve potasiyel ek yaralanmaların eş zamanlı tedavi edilmesi gibi avantajlar sunmakla beraber her iki cerrahi tedavide de benzer klinik sonuçlar elde edilmektedir. Operasyon süresinin daha uzun olması ve uzun öğrenme eğrisi artroskopik tedavinin dezavantajlarını olușturmaktadır.

Anahtar Kelimeler: El bileği artroskopisi, dorsal ganglion, artroskopik ganglionektomi
Address for Correspondence/Yazıșma Adresi: Tahsin Gürpınar MD, University of Health Sciences Turkey, İstanbu

Training and Research Hospital, Clinic of Orthopedics and Traumatology, İstanbul, Turkey

Phone: +90 5056856439 E-mail: tahsingurpinar@msn.com ORCID ID: orcid.org/0000-0002-8194-6492

Cite this article as/Atıf: Gürpınar T, Çarkçı E. Prospective Outcomes of Arthroscopic Versus Open Resection of Dorsal Wrist Ganglions. İstanbul Med J 2020; 21(2): 104-8.
Received/Geliș Tarihi: 29.12.2019 Accepted/Kabul Tarihi: 07.02.2020

(C) Copyright 2020 by the University of Health Sciences Turkey, Istanbul Training and Research Hospital/istanbul Medical Journal published by Galenos Publishing House.

(C) Telif Hakkı 2020 Sağgık Bilimleri Üniversitesi İstanbul Ĕğitim ve Araştırma Hastanesi/listanbul Tıp Dergisi, Galenos Yayınevi tarafından basılmıștır. 


\section{Introduction}

Dorsal wrist ganglions are the most common benign tumour of the hand and they mostly remain asymptomatic $(1,2)$. Most common causes of ganglion cysts are known as scapholunate ligament injuries, tendon stealth pathologies and synovial herniations (3).

Almost half of the wrist ganglions spontaneously disappear within time, but some can cause functional limitations, pain or cosmetic problems (3). Main symptoms are usually pain, reduced range of motion or decreased grip strength. The first-line of the treatment is non-surgical options like observation, aspiration or intralesional steroid injections but recurrences can be seen up to $78 \%$ of the cases (4). Open or arthroscopic surgery is the preferred treatment for recurrent cases and for patients who wish surgery as the initial treatment.

Open excision of wrist ganglions is the conventional method of surgical treatment but arthroscopic surgery has become popular since it was described by Osterman and Raphael (5). In the literature, the recurrence rates are similar but faster postoperative recovery time, decreased postsurgical pain, early return to work and less scar formation favours arthroscopic excision over open excision (6). The aim of this prospective randomized study was to compare recurrence, postoperative pain and functional scores of the patients operated with open or arthroscopically due to dorsal wrist ganglion with a minimum of 18-month follow-up.

\section{Methods}

The study was performed at a single institution between August 2017 and December 2017. All surgeries were done by the same surgeon. The Institutional Review Board of İstanbul Training and Research Hospital approved this study with the issue number 1042 and consent form was obtained from all patients. Fourty patients having dorsal wrist ganglion cysts, who failed conservative treatment for a minimum of six months, were prospectively registered in this study. Twenty patients had arthroscopic surgery and 20 patients had open excision. Conservative treatment involved anti-inflammatory drugs, splinting and aspiration. The exclusion criteria were previous surgery, a history of a fracture, ligamentous tears and wrist instability. Patients who agreed to partake in the study were randomly assigned to have open or arthroscopic excision. Randomization was performed at initial presentation by assigning patients with odd-numbered patient id numbers to the open excision group and even-numbered patient id numbers to the arthroscopic excision group.

All patients were examined just before the operation and at the postoperative last follow-up. The clinical and functional outcomes were measured with The Disabilities of the Arm, Shoulder and Hand (QuickDASH) score and grip strength. Pain was assessed with Visual Analogue Pain scale (VAS). Furthermore, patients' demographic characteristics, time from diagnosis to surgery, operation time, incision lengths, recurrence rates, and treatment satisfaction rates were compared.

\section{Surgical Technique}

The open technique was done under local anaesthesia. A transverse skin incision was made in 2 to $3 \mathrm{~cm}$ length (Figure 1A). Tourniquet was not used but meticulous homeostasis was achieved for visualization. The cyst was removed with the base of the ganglion stalk and with a portion of the dorsal wrist capsule (Figure 1B).

The arthroscopic technique was performed under general anaesthesia and traction. We used a $30^{\circ}$ visual angle $2.7 \mathrm{~mm}$ arthroscope and isotonic saline solution. We used 4-5 portal for the purpose of visualization. 3-4 portal was then opened and used for instrumentation (Figure 2A). We used an arthroscopic shaver to debride the ganglion to scapholunate ligament and the stalk with a portion of the capsule (Figure 2B). After the excision of the ganglion, a $1-2 \mathrm{~cm}$ void was opened in the capsule. If dorsal synovitis was observed, it was also debrided. Meticulous care was taken to protect the extensor tendons. For both groups, splints were removed and active and passive exercises were started at the first visit at the $1^{\text {st }}$ week and sutures were removed at the $2^{\text {nd }}$ week.

\section{Statistical Analysis}

Mean, standard deviation, median, minimum, maximum value frequency and percentage were used for descriptive statistics. The distribution of variables was checked with Kolmogorov-Simirnov test. Independent samples t-test and Mann-Whitney $U$ test were used for the comparison of quantitative data. Wilcoxon test was used for the repeated measurement analysis. Chi-square test was employed for the comparison of the qualitative data. SPSS 22.0 was used for statistical analyses.

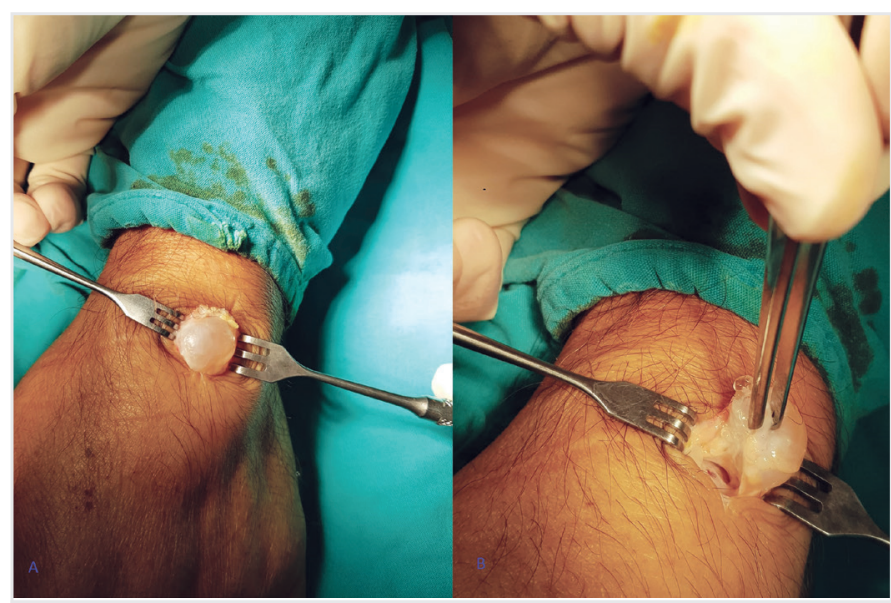

Figure 1A, 1B. Surgical images of open dorsal ganglion cyst excision

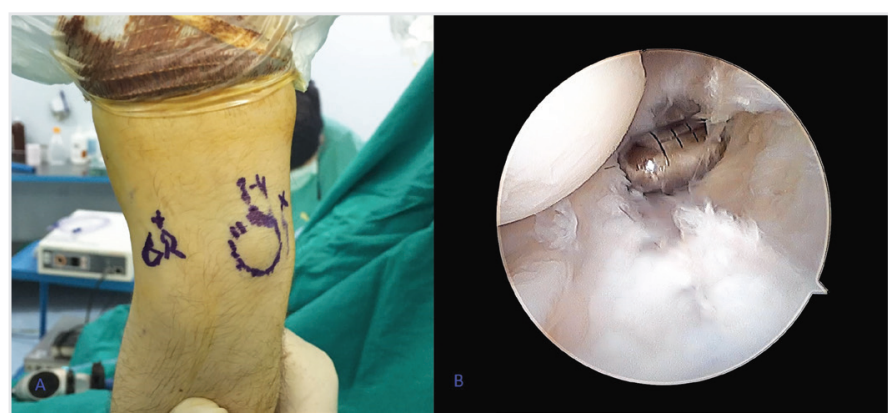

Figure 2A. Image of portals in the excision of arthroscopic dorsal ganglion cyst, 2B. Arthroscopic view of the shaver excision of the dorsal ganglion cyst 


\section{Results}

The study group consisted of 25 (62.5\%) female and 15 (37.5\%) male patients with a mean age of $26.3 \pm 5.3$ years (range, $18-43$ years). In the open and arthroscopy groups, age, gender, side distribution and dominant side distribution were not significantly different ( $p>0.05)$.

Although the postoperative QuickDASH score and VAS decreased significantly in the open and arthroscopic groups compared to the preop period $(p<0.05)$, there was no substantial difference between two groups regarding preop and postop values. In the open and arthroscopy groups, preop and postop grip strength values did not differ statistically $(p>0.05)$. In the open and arthroscopy groups, the time from diagnosis to surgery did not differ statistically ( $p>0.05$ ). The operative time was significantly longer in the arthroscopy group than in the open surgery group $(p<0.05)$. In the arthroscopy group, the incision length was significantly lower than in the open surgery group $(p<0.05)$. In the open and arthroscopic groups, the recurrence rate was similar ( $p>0.05)$. In the open and arthroscopy groups, the rate of satisfaction with the treatment did not change significantly ( $p>0.05$ ) (Table 1$)$.

In both of the groups, there were 2 recurrences during follow-ups (10\%), which were treated with open excision. Extensor tendon rupture was not observed in any group; however, one of the patients had extensor tenosynovitis which lasted for 6 months after surgery and limited full flexion of the wrist. No other complications were reported.

\section{Discussion}

Arthroscopic surgery of the hand and wrist continue to expand in wrist pathologies such as triangular fibrocartilage complex (TFCC) injuries, intra-articular ligament tears and scaphoid fractures $(7,8)$. Likewise arthroscopic dorsal ganglion resection has been performed with satisfactory outcomes since it was first described by Osterman and Raphael (5). The results of our study showed that arthroscopic excision of dorsal wrist ganglions provides respectable clinical outcomes with elevated patient satisfaction, as reported in previous studies (9-11). The

Table 1. Comparison of demographic characteristics, clinical and functional results of open and arthroscopic groups

\begin{tabular}{|c|c|c|c|c|c|c|c|}
\hline \multirow{3}{*}{ Age } & & \multicolumn{2}{|l|}{ Open } & \multicolumn{2}{|l|}{ Artroscopic } & \multirow{2}{*}{\multicolumn{2}{|c|}{$\mathbf{p}$}} \\
\hline & & Mean \pm SD/ $(n \%)$ & Median & Mean \pm SD /(n\%) & Median & & \\
\hline & & $26.9 \pm 5.7$ & 26.0 & $25.8 \pm 4.9$ & 26.0 & 0.537 & $\mathrm{t}$ \\
\hline \multirow{2}{*}{ Sex } & Male & $7(35.0 \%)$ & - & $8(40.0 \%)$ & - & \multirow{2}{*}{0.744} & \multirow{2}{*}{$X^{2}$} \\
\hline & Female & $13(65.0 \%)$ & - & $12(60.0 \%)$ & - & & \\
\hline \multirow{2}{*}{ Side } & Left & $8(40.0 \%)$ & - & $8(40.0 \%)$ & - & \multirow{2}{*}{1.000} & \multirow{2}{*}{$X^{2}$} \\
\hline & Right & $12(60.0 \%)$ & - & $12(60.0 \%)$ & - & & \\
\hline \multirow{2}{*}{ Dominant } & Left & $1(5.0 \%)$ & - & $3(15.0 \%)$ & - & \multirow{2}{*}{0.292} & \multirow{2}{*}{$X^{2}$} \\
\hline & Right & $19(95.0 \%)$ & - & $17(85.0 \%)$ & - & & \\
\hline \multicolumn{8}{|l|}{ QuickDASH score } \\
\hline \multicolumn{2}{|l|}{ Preoperative } & $14.1 \pm 7.8$ & 12.0 & $11.8 \pm 5.8$ & 9.5 & 0.356 & $\mathrm{~m}$ \\
\hline \multicolumn{2}{|l|}{ Postoperative } & $0.7 \pm 0.8$ & 0.0 & $0.7 \pm 0.9$ & 0.5 & 0.870 & $\mathrm{~m}$ \\
\hline \multicolumn{2}{|l|}{ Intra group difference $p$} & 0.000 & w & 0.000 & w & - & - \\
\hline \multicolumn{8}{|l|}{ VAS } \\
\hline \multicolumn{2}{|l|}{ Preoperative } & $4.2 \pm 0.7$ & 4.0 & $4.2 \pm 0.8$ & 4.0 & 0.834 & $\mathrm{~m}$ \\
\hline \multicolumn{2}{|l|}{ Postoperative } & $0.4 \pm 1.0$ & 0.0 & $0.4 \pm 0.8$ & 0.0 & 0.791 & $\mathrm{~m}$ \\
\hline \multicolumn{2}{|l|}{ Intra group difference $p$} & 0.000 & w & 0.000 & w & - & - \\
\hline \multicolumn{8}{|l|}{ Grip strenght } \\
\hline \multicolumn{2}{|l|}{ Preoperative } & $29.9 \pm 8.6$ & 26.5 & $31.5 \pm 7.9$ & 29.0 & 0.378 & $\mathrm{~m}$ \\
\hline \multicolumn{2}{|l|}{ Postoperative } & $30.4 \pm 7.8$ & 28.0 & $31.6 \pm 7.5$ & 30.0 & 0.480 & $\mathrm{~m}$ \\
\hline \multicolumn{2}{|l|}{ Intra group difference $p$} & 0.303 & w & 0.322 & w & - & - \\
\hline \multicolumn{2}{|c|}{ Time from diagnosis to surgery (month) } & $11.7 \pm 3.6$ & 12.0 & $10.9 \pm 3.4$ & 10.0 & 0.442 & $\mathrm{~m}$ \\
\hline \multicolumn{2}{|l|}{ Operation time (minute) } & $21.0 \pm 5.0$ & 20.0 & $33.3 \pm 4.7$ & 32.5 & 0.000 & $\mathrm{~m}$ \\
\hline \multicolumn{2}{|l|}{ Incision length (mm) } & $34.5 \pm 4.1$ & 34.0 & $9.3 \pm 1.2$ & 9.0 & 0.000 & $\mathrm{~m}$ \\
\hline \multirow{2}{*}{ Recurrence } & $(-)$ & $18(90.0 \%)$ & - & $18(90.0 \%)$ & - & \multirow{2}{*}{1.000} & \multirow{2}{*}{$X$} \\
\hline & $(+)$ & $2(10.0 \%)$ & - & $2(10.0 \%)$ & - & & \\
\hline Treatment Saticfaction & $(-)$ & $3(15.0 \%)$ & - & $2(10.0 \%)$ & - & 063 & $X^{2}$ \\
\hline 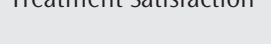 & $(+)$ & $17(85.0 \%)$ & - & 18 (90.0\%) & - & נכנ0. & \\
\hline
\end{tabular}


patients' reported outcome measures in both arthroscopic and open groups are also comparable in our study similar to the literature.

The pain was the main symptom in our cases. The mean VAS decreased from 4.2 to 0.4 at last follow-up in both arthroscopic and open groups. Chassat et al. (12) reported that the pain decreased from 3.37 to 1.76 after arthroscopic resection. Decreased pain scores are also reported in previous series (13). On the other hand, Lee et al. (14) reported 20\% residual or persistent pain after arthroscopic excision whereas none in the open surgery group. In our study, the pain scores and postoperative alleviation of symptoms were comparable between the open and arthroscopic groups.

Recurrence of the ganglions is the most common reported complication of any treatment. $(15,16)$ We reported 4 recurrences $(10 \%): 2$ in the arthroscopic and 2 in the open group in minimum of 18-month follow up. Rizzo et al. (17) reported 2 recurrences in 41 patients with a followup of 2 years. Mathoulin et al. (18) reported 4 recurrences in 96 patients with an average follow-up of 34 months. However, in another study, Chassat et al. (12) reported 16 recurrences in 54 dorsal wrist ganglia (29.7\%) following arthroscopic excision at an average follow-up of 28 months. Recurrence rates after open excision are also variable. In a recent systemic review, Crawford et al. (19) found recurrence rate of arthroscopic excision as $7.9 \%$ whereas $9.8 \%$ for open excision when poor quality studies were excluded. Based on the relevant literature, arthroscopic excision of dorsal wrist ganglion has recurrence rates similar to the open technique. However, we believe that the most important reason of recurrence is incomplete excision of the stalk or the existence of multiple cysts which are not removed after arthroscopy or open surgery.

Dominant side, younger ages and female gender are reported to be the most substantial risk factors for recurrence following arthroscopic resection of wrist ganglions in the literature (20). In our small cohort, the mean age of the patients was 26.8 years in the arthroscopic group and 27 years for the open group. However, the ages of the patients with recurrence were 26, 32, 19 and 26 years, and no correlation was observed with age. On the other hand, all of the four recurrences were observed on the dominant side. In addition, three of the patients were female whereas one was male.

Complications such as stiffness, neuroma, hematoma, wound problems, neuropraxia or paresthesia, vascular injury, infection and extensor tenosynovitis were reported in the literature after open ganglion resections. $(19,21,22)$ However, these complications are also possible after arthroscopic surgery. Kang et al. (6) compared outcomes of arthroscopic and open resection of 72 ganglions and they reported a case of neuropraxia of the superficial radial nerve, which was resolved after neurolysis in the arthroscopic group whereas no complication was reported in the open group. Fernandes et al. (11) reported one hypertrophic scarring after 34 arthroscopic resections. Edwards and Johansen (23) reported three extensor tenosynovitis after 55 arthroscopic surgeries. One of our patients had extensor tenosynovitis which lasted for six months after surgery and limited full flexion of the wrist. On the other hand, we did not observe any complication on the open group.
Post-surgical follow-up varies in the literature. We did not immobilize the wrist joint and only did a soft dressing as recommended by Nishikawa et al. (10). On the other hand, many authors choose immobilization for 7-10 days and avoid strenuous activity for few weeks $(6,17)$.

An advantage of arthroscopic resection of dorsal ganglions are considered to be able to interfere coexisting intraarticular pathologies. Osterman and Raphael (5) reported that almost half of the patients had intraarticular pathologies and most commonly a scapholunate interosseous ligament tear. Likewise, Edwards and Johansen (23) claimed that all of the patients with dorsal wrist ganglions also had ligament instabilities. Kang et al. (24) reported intraarticular pathologies with dorsal wrist ganglions in 21 of 41 patients, such as TFCC and intrinsic ligament tears (23). We diagnosed scapholunate interosseous ligament tear in seven patients and grade 1 TFCC tear in one patient who underwent arthroscopic ganglion excision. We have not performed any arthroscopic repair to any identified coexisting intraarticular pathology; however, this may be because of our lack of experience in wrist arthroscopy and we may have underestimated the potential ligament laxity or other pathologies. On the other hand, a recent study showed that additional intraarticular pathologies did not affect functional outcomes after arthroscopic excision of dorsal ganglions (24).

One of the advantages of arthroscopic surgery is better cosmetic outcome. The small portals are only millimeters in length and scars are almost invisible after wound healing. In our study, the average scar length was $34.5 \mathrm{~mm}$ in the open group and $9.3 \mathrm{~mm}$ in the arthroscopic group. They healed faster and almost all of the patients in our study were satisfied with the cosmetic outcome.

\section{Study Limitations}

This study has some limitations. The main limitations are the small number of patients, the absence of a control group, and relatively short follow-up period. In addition, we could not repair interosseous ligamentous instability because of lack of experience.

\section{Conclusion}

Arthroscopic ganglionectomy has advantages of smaller scars, diagnosing and treating coexisting disorders of the wrist. Disadvantages are steep learning curve and long operating time.

\section{Ethics}

Ethics Committee Approval: The Institutional Review Board of University of Health Sciences Turkey, İstanbul Training and Research Hospital approved this study (Decision no: 1042, date: 21.07.2017)

Informed Consent: Consent form was obtained from all patients.

Peer-review: Externally and internally peer-reviewed.

Authorship Contributions: Surgical and Medical Practices - T.G.; Concept - T.G.; Design - T.G.; Data Collection and/or Processing - T.G.; Analysis and/or Interpretation - T.G., E.Ç.; Literature Search - T.G., E.Ç.; Writing Manuscript - T.G., E.C.

Conflict of Interest: No conflict of interest was declared by the authors.

Financial Disclosure: The authors declared that this study received no financial support. 


\section{References}

1. Meena S, Gupta A. Dorsal wrist ganglion: Current review of literature. J Clin Orthop Trauma 2014; 5: 59-64.

2. Thornburg LE. Ganglions of the hand and wrist. J Am Acad Orthop Surg 1999; 7: 231-8.

3. Gude W, Morelli V. Ganglion cysts of the wrist: pathophysiology, clinical picture, and management. Curr Rev Musculoskelet Med 2008; 1: 205-11.

4. Suen M, Fung B, Lung CP. Treatment of ganglion cysts. ISRN Orthop. 2013; 2013: 940615.

5. Osterman AL, Raphael J. Arthroscopic resection of dorsal ganglion of the wrist. Hand Clin 1995; 11: 7-12.

6. Kang L, Akelman E, Weiss AP. Arthroscopic versus open dorsal ganglion excision: a prospective, randomized comparison of rates of recurrence and of residual pain. J Hand Surg Am 2008; 33: 471-5.

7. Wagner J, Ipaktchi K, Livermore M, Banegas R. Current indications for and the technique of wrist arthroscopy. Orthopedics 2014; 37: 251-6.

8. Wolf JM, Dukas A, Pensak M. Advances in wrist arthroscopy. J Am Acad Orthop Surg 2012; 20: 725-34

9. Mathoulin C, Gras M. Arthroscopic Management of Dorsal and Volar Wrist Ganglion. Hand Clin 2017; 33: 769-77.

10. Nishikawa S, Toh S, Miura H, Arai K, Irie T. Arthroscopic diagnosis and treatment of dorsal wrist ganglion. J J Hand Surg Br 2001; 26: 547-9.

11. Fernandes CH, Meirelles LM, Raduan Neto J, Fernandes M, Dos Santos JBG, Faloppa F. Arthroscopic Resection of Dorsal Wrist Ganglion: Results and Rate of Recurrence Over a Minimum Follow-up of 4 Years. Hand (N Y) 2019; 14: 236-41.

12. Chassat R, Nourissat G, Chaumeil G, Dumontier C. [Arthroscopic treatment of dorsal ganglion cyst at the wrist. About 54 cases]. Chir Main 2006; 25: 146-51.

13. Rocchi L, Canal A, Pelaez J, Fanfani F, Catalano F. Results and complications in dorsal and volar wrist Ganglia arthroscopic resection. Hand Surg 2006; 11: 21-6.
14. Lee HLL, Lee KH, Koh KH, Won HJ, Cho HK, Park MJ. Excision of painful dorsal wrist ganglion by open or arthroscopic approach : a compariso $\mathrm{n}$ study. Acta Orthop Belg 2017; 83: 315-321.

15. Zeidenberg J, Aronowitz JG, Landy DC, Owens PW, Jose J. Ultrasound-guided aspiration of wrist ganglions: a follow-up survey of patient satisfaction and outcomes. Acta Radiol 2016; 57: 481-6.

16. Kulinski S, Gutkowska O, Mizia S, Gosk J. Ganglions of the hand and wrist: Retrospective statistical analysis of 520 cases. Adv Clin Exp Med 2017; 26: 95100.

17. Rizzo M, Berger RA, Steinmann SP, Bishop AT. Arthroscopic resection in the management of dorsal wrist ganglions: results with a minimum 2-year followup period. J J Hand Surg Am 2004; 29: 59-62.

18. Mathoulin C, Hoyos A, Pelaez J. Arthroscopic resection of wrist ganglia. Hand Surg 2004; 9: 159-64

19. Crawford C, Keswani A, Lovy AJ, Levy I, Lutz K, Kim J, et al. Arthroscopic versus open excision of dorsal ganglion cysts: a systematic review. J Hand Surg Eur Vol 2018; 43: 659-64

20. Kim JP, Seo JB, Park HG, Park YH. Arthroscopic excision of dorsal wrist ganglion: factors related to recurrence and postoperative residual pain. Arthroscopy 2013; 29: 1019-24.

21. Balazs GC, Donohue MA, Drake ML, Ipsen D, Nanos GP, Tintle SM. Outcomes of Open Dorsal Wrist Ganglion Excision in Active-Duty Military Personnel. J Hand Surg Am 2015; 40: 1739-47.

22. Khan PS, Hayat H. Surgical excision versus aspiration combined with intralesional triamcinolone acetonide injection plus wrist immobilization therapy in the treatment of dorsal wrist ganglion; a randomized controlled trial. J Hand Microsurg 2011; 3: 55-7.

23. Edwards SG, Johansen JA. Prospective outcomes and associations of wrist ganglion cysts resected arthroscopically. J Hand Surg Am 2009; 34: 395-400.

24. Kang HJ, Koh IH, Kim JS, Choi YR. Coexisting intraarticular disorders are unrelated to outcomes after arthroscopic resection of dorsal wrist ganglions. Clin Orthop Relat Res 2013; 471: 2212-8. 